\title{
4 Spanish soft power and its structural (non-traditional) model of diplomacy
}

\author{
Alberto Priego Moreno
}

Over the last 40 years, Spain has undergone a historic process of reforms to modernize the country. In political terms, Spain has adopted a democratic system grounded in well-organized political parties, a fledgling civil society and a responsible citizenship. Despite the current credit crunch, the Spanish economy may be deemed modern and is comparable to the most developed economies of the world. Not in vain, Spain is in some of the most important global economic forums such as the World Economic Forum, G20 and the OECD. In the private sector, Spanish multinational companies (such as Repsol, Abengoa, Santander Bank, BBVA and Zara) are present in all the five continents. At the level of civil society, celebrities such as Antonio Banderas, artists such as Picasso or sportsmen such as Rafael Nadal have also helped to raise the prestige of Spain.

In this process of modernization, I must highlight a public instrument: diplomacy and the actions of Spanish diplomats. Spanish diplomacy has been the main vehicle of change abroad. Thus, this chapter will analyse the role of diplomacy in the transformation of Spain from Franco's death (1975) to the end of Prime Minister Zapatero's second term (2011). During this long period of 36 years, all Spanish governments - regardless of their ideology - have tried to adopt a new model of diplomacy (Barston 2006: 3). This change has been motivated by two main factors: first, the evolution of the diplomatic institution itself and, second, the transformation of Spain into a modern and competitive country.

The evolution of the diplomatic institution. Modern diplomacy - as we conceive it today - dates back to the fifteenth century. It is a traditional model of diplomacy that has changed over time. Most of the authors consider that the traditional approach to diplomacy remained unaltered until the second half of the twentieth century (Cross 2007: 33). This view of diplomacy was based on the states as the main actors and bilateralism as their means of relations. However, the end of the Cold War and other dynamics of international society altered the nature of diplomacy. The doctrine of international relations has identified three fundamental changes in the nature of the diplomatic institution (Keukeleire, Thiers et al. 2009) 
A broader diplomatic agenda that includes a diversification of the issues to be treated by the diplomatic agents. These issues, like nuclear proliferation or environmental questions, exceed the bilateral relationship and reach the regional or even the global dimension. The inclusion of these new topics into the diplomatic agenda has led the diplomats to need expertise in new areas such as democratization, economy or security issues. In this sense, this need for specialization has led governments to incorporate non-diplomat officers to their diplomatic missions.

The involvement of new actors in the diplomatic process. Historically, classic diplomacy has been a domaine reserve for states only. However, this conception of diplomacy, which is deeply linked to the realist theory of international relations, needs to be revised (Berridge et al. 2001: 88). The emergence of non-state actors - NGOs, international companies, think-tanks, etc. - has affected the inter-state traditional conception of diplomacy (Manfredi 2011).

The emergence of new international forums to develop diplomacy. As I mentioned before, diplomacy has traditionally been either an inter-state activity or developed in the bosom of the international organizations. In the last decades, though, international society has witnessed the rise of a number of informal meetings under new labels such as forums, summits or dialogues. The G20, the Barcelona Process (EU), the 5+5 Dialogue and the Alliance of Civilization could be considered proper examples or this phenomenon. It is a new, more flexible format that permits the inclusion of new topics such as cultural affairs or environmental issues and new actors such as NGOs or regional bodies. Some authors have used the term 'summitry' to describe this new phenomenon (Berridge 2010: 166)

The modernization of Spain. The modernization of Spain has implied a deep transformation process. Since Franco's death, Spain has carried out a modernization project that culminated with the integration into the North Atlantic Treaty Organization (NATO) 0in 1981 and into the European Union in 1986. In this way, international society acknowledged the effort of 'this new and democratic Spain' with the award of several important international events. In 1982 Spain organized the football World Cup and ten years later Barcelona hosted the 25th Summer Olympic Games. In the cultural field, Spain has been the venue for the International Exhibition twice; the first one in Seville 1992 and the second in Zaragoza 16 years later, in 2008.

In spite of this international recognition, Spain still dragged a heavy heritage of authoritarianism, isolation and backwardness that seriously affected its image. Thus, the modern democracy needed to transform its image in order to be more attractive. In a highly interdependent and competitive world, all the states need to be more and more appealing to attract foreign direct investment. Besides, the case of Spain is not an exception and, of course, foreign investment and tourism are crucial for the economy.

In turn, Spanish companies tried to find a way to obtain natural resources, reduce their costs and find new markets for their products. To that end, top companies required the government to improve Spain's image and facilitate 


\section{Alberto Priego Moreno}

their business and investment projects abroad. The Spanish government launched an international campaign based on those elements that Spain could offer. This campaign, which has been based on soft power, has tried to construct a 'New Spain' image, to appear attractive enough for tourists, investors and foreign governments, amongst others. The process cannot be considered a purely public initiative because, as a consequence of globalization, new actors such as companies, NGOs and individuals have played an important role in the international transformation of Spain. These actors, who usually enjoy prestigious positions, have the ability to reach where governments simply cannot.

In other words, in the 1980s the new democratic Spain assumed that social change and political transition were not enough to improve its role in international society. To this end, Spain started to use soft power through its diplomacy to be more effective to achieve its goals.

For this reason, at the beginning of the 1980s Spain addressed a deep transformation of its diplomacy, passing from a traditional model to a nontraditional one. This process, whether successful or not, can be considered a good example of structural diplomacy, the main aim of which is modernization of Spain in general and its foreign policy in particular.

\section{Concepts and definitions}

Diplomacy is a concept traditionally used in an improper or at least unsuitable way. One of the aims of this chapter is to provide an accurate definition of concepts such as diplomacy, public diplomacy, national branding, cultural diplomacy, and so on.

First of all it is important to clarify the relation between diplomacy and foreign policy. Diplomacy and foreign policy are not synonymous, although some experts consider or at least assume that there is no difference between these two terms. However, the Ministry of Foreign Affairs is responsible for the formulation of the foreign policy which is implemented through diplomats. According to Juergen Kleiner, diplomacy should manage to achieve the goals established by the Ministry of Foreign Affairs (Kleiner 2008). Thus, diplomacy is an essential tool for the implementation of foreign policy and both (foreign policy and diplomacy) terms are neither synonymous nor antonymous. Thus they are complementary concepts instead.

The fact is that diplomacy is a very fluid concept and therefore there is no consensus about what diplomacy exactly is. If we look at Sir Peter Marsall's works, we find at least six different meanings for diplomacy (McKercher 2012). First, diplomacy can be understood as the content of foreign affairs. According to this meaning, diplomacy and foreign affairs can be inter-related. A second connotation of diplomacy is related to the conduct or behaviour of foreign policy. Henry Kissinger is one of the authors, most of them realists, who consider that diplomacy is just the ability of managing foreign affairs. In other words, for these authors diplomacy and statecraft are the same tenet. In 
fact, one of the most prestigious journals in the field is Diplomacy and Statecraft. Even more, other authors such as Hans Morgenthau or Raymond Aron established a compatible and logic relation between war and diplomacy. These authors argue that diplomacy and war are complementary realities.

A third and very classic realm of diplomacy is negotiation. This meaning of diplomacy implies a peaceful conception which contradicts the previous one. Notable authors, such as Martin Wight and Harold Nicholson, consider that negotiation is the essential point of diplomacy. Geoff R. Berridge distinguishes between pre-negotiation and negotiation as two different phases of this important aspect of diplomacy (Berridge 2010). Kleiner reasserts the same idea, considering that negotiation is a special part of diplomacy because it tries to reach an understanding through discussion (Kleiner 2008: 323). One of the most important theorists of modern diplomacy, Adam Watson, established a definition of diplomacy based on this function. Watson considers that diplomacy is a negotiation among political entities which acknowledged each other. In fact, an important share of the doctrine identifies diplomacy and negotiation. The Vienna Convention on Diplomatic Relations sanctioned in its article 3.e that 'negotiating with the Government of the receiving State' is one of the functions of the diplomatic missions.

Sir Peter Marshall brings a fourth sense of the word diplomacy. According to the British author, diplomacy might be understood as 'corps of officials working for their state'. In other words, in this context it means diplomatic service or diplomats. Another meaning for diplomacy, the fifth one following Sir Peter Marshall's contribution, is the adjective 'diplomatic' (McKercher 2012). I am talking about the adjective used to refer to a peaceful and wellmannered mode of action. Quoting Winston Churchill, diplomacy is the art of telling people go to hell, and, I can add, in a polite way. The last connotation of diplomacy could be explained as the skill of being a professional diplomat.

There are some concepts such as cultural diplomacy, national branding or public diplomacy, that hold certain semantic similarities with diplomacy. For that reason, most of them deserve some attention.

The first concept I am going to analyse is public diplomacy. Public diplomacy, one of the key elements of soft power, is a term created and developed by Edmund Gullion a former Dean of the prestigious Fletcher School of Law and Diplomacy. Unlike him, Geoffrey Berridge adopted a very critical position with public diplomacy. According to Berridge, who is one of the most prestigious experts on diplomatic studies, public diplomacy is a soft euphemism for propaganda (Berridge 2010). A leading American diplomat of our times, Richard Holbrooke, shares Berridge's opinion about public diplomacy. Ambassador Holbrooke pointed out that whatever it is called, public diplomacy always will be propaganda.

A greatly respect theorist on diplomacy, Paul Sharp, considers that public diplomacy is 'the process by which direct relations with people in a country are pursued to advance the interests and extend the values of those being 
represented' (Mellisen 2007:11) Another important author, Hans Tuch, defines public diplomacy as 'a government's process of communicating with foreign publics in an attempt to bring about understanding for its nation's ideas and ideals, its institutions and culture, as well as, its national goals and policies' (Mellisen 2007: 11-12)

Another term of interest for this chapter is cultural diplomacy. Milton Cumming established the most accepted definition of cultural diplomacy which is defined as 'the exchange of ideas, information, art and other aspects of culture among nations and their peoples to foster mutual understanding' (Cummings 2003:1). Cultural diplomacy is a concept highly intertwined with other terms, such as cultural relations. Taylor attributes the creation of the concept to the French when they tried to promote republican values to soften their defeat at the hand of the Prussian army. According to Benno Signitzer, this approach to cultural diplomacy is one of the two functions of public diplomacy. The Austrian professor distinguishes between political information and cultural communication. While the first one is carried out by the Ministry of Foreign Affairs, the second is usually implemented by some agencies specializing in cultural issues. The best example is the now extinct United States Information Agency.

Another concept of relevance for this study is national branding. Peter van Ham states that the concept 'brand' is linked to products and services with an emotional dimension (Van Ham 2001:2) because people can identify with them. Over the last decades some nations have adopted some public diplomacy actions based on national branding as a way to improve their international image. We are talking about national reputation, which is 'collective judgments of a foreign country's image' (Ashari 2012: 1)

Thus, cultural diplomacy, national branding and national reputation are a substantial part of public diplomacy, a concept that contains an important dose of soft power. According to Nye, soft power is 'The ability to get what you want through attraction rather than coercion or payments' (Nye 2004:7) and this is one of the objectives of public diplomacy.

In any case, it is clear that public diplomacy should be considered an important aspect of non-traditional diplomacy but not a model of diplomacy itself. Among the supporters of this non-traditional vision of diplomacy, I highlight the work of Stephan Keukeleire. The author created a new concept structural diplomacy - that could be defined as 'the process of dialogue and negotiation by which actors in the international system seek to influence or shape sustainable external political, legal, economic, social and security structures at different relevant levels in a given geographic space' (Keukeleire et al. 2009: 146). Keukeleire attributes two aspects to the word 'structural'. The first is to shape or exert an influence in the structure. In this sense, Keukeleire clarifies what should be understood by structure: organizing principles, rules of the game and institutions. The second element of the adjective 'structural' refers to a long-term approach of this influence. It is for this reason that Keukeleire admits that structural diplomacy should contribute to the sustainability of 
these international structures (organizing principles, rules of the game and institutions).

Once we have clarified all the concepts and terms related to diplomacy, we are in a position to choose the most adequate approach to assess the evolution of Spanish diplomacy from Franco's death to the end of Zapatero's second term. Current fashionable concepts - such as public or cultural diplomacy, national branding, or national reputation - are only small aspects of structural diplomacy, the concept encompasses which all these non-traditional approaches to diplomacy. In order to analyse the evolution of the Spanish diplomatic institution, I will use Keukeleire's vision of structural diplomacy.

\section{Spanish strategy towards a non-traditional model of diplomacy}

Once I have described and clarified basic concepts of diplomacy, I will explain how Spain fits into this theoretical framework. In my opinion, structural diplomacy is the best theoretical option to analyse the evolution of Spanish diplomacy. Although Spain is trying to adapt its diplomacy to the current international system in order to promote a more attractive image, the main guidelines are truly inspired on the two aspects highlighted by the structural diplomacy model.

First, all the efforts carried out by the Ministry of Foreign Affairs are aimed to exert a substantial influence in the core of the international system. So, Spanish diplomacy has been trying to shape basic principles, essential rules and accepted customs of international society. In recent years, Spain has proposed, created and led important and hopeful initiatives to remodel relations among different international actors. Probably the best examples of this nontraditional approach are the Ibero American Community of Nations, the Barcelona Process and the Alliance of Civilizations. These three Spanish initiatives will be analysed in detail later.

Second, this vocation of influence in international society should be understood as a long-term approach. In other words, Spain has become an actor which looks after the stability of the international system. To that end, this new Spanish diplomacy cannot be aggressive or intolerant and, overall, should be based on legitimate and sustainable actions. In this sense, the aim of Spanish diplomacy is that Spain's partners can perceive its willingness to strengthen bilateral relations and the sustainability of the international system.

Following a non-traditional approach to diplomacy, David J. Wellman has expressly alluded to the relation between Morocco and Spain to define sustainable diplomacy (Constantinou and Der Derian 2010: 25). In this case, Morocco understands that its relationship with Spain is based on mutual respect and equality. On the one hand, Spain seeks to understand the Moroccan point of view and tries to solve common problems such as migration or drug trafficking in the Strait of Gibraltar; on the other hand, Morocco understands the Spanish point of view while recognizing its contribution to the strengthening of the international system through multilateral initiatives such as the 
Alliance of Civilizations or the NATO Mediterranean Dialogue. In short, I can point out that Spain seeks to adapt to the new challenges of the international system and improve its image through the model of structural diplomacy.

\section{The (new) public diplomacy: between soft power and national branding}

Public diplomacy is a fundamental aspect of the structural diplomacy model. Needless to say, the most successful model of public diplomacy is that of the United States. However, Spain does not base its public diplomacy on the North American model. Probably, due to geographical and cultural reasons, the Spanish model of public diplomacy is closer to the British and the French ones. It is for this reason that I consider it appropriate to provide a brief description of the European models of public diplomacy before dealing with the Spanish one.

The French Ministry of Foreign Affairs (Ministère des Affaires Etrangere et Europeens) is in charge of the promotion of public diplomacy, among other tasks. There are two Directorate-Generals: the Direction generale des affairs et securite is responsible for traditional diplomatic affairs, whereas the Direction generale de la mondialization, du developpement et des parteniariats manages non-traditional issues such as cooperation and development, cultural diplomacy and international economic relations. This second Directorate-General is responsible for the policy of French public diplomacy. In recent years, the French Ministry of Foreign Affairs has undertaken major reforms and, in this sense, France has opted for cultural diplomacy as a key point of its public diplomacy model. The most important body in this regard is the Institute Français, which monopolizes the cultural activities abroad and is an independent actor in the general framework of French public diplomacy (Alonso et al. 2012: 53).

The second model of public diplomacy which will be subject of this analysis is the British one. The Foreign and Commonwealth Office (FCO) is the main body responsible for the public diplomacy policy. The FCO, which has attached more and more importance to non-traditional diplomacy, relies on three departments for public diplomacy: Press and Digital; Internal Communication; and Communication and Engagement. The latter is formally responsible for public diplomacy through the Public Diplomacy Unit. Nevertheless, the other two departments have also played an important role in the execution of British public diplomacy (Alonso et al. 2012: 53). The BBC World Service and the British Council might be highlighted as the major agents of the British public diplomacy. Currently, British diplomacy is deeply focused on a national (re)branding process called 'Great Campaign' whose major spots are 'Innovation is Great ... Britain' or 'Culture is Great ... Britain'

The Spanish model of public diplomacy is a combination of the French and the British ones. On the one hand the involvement of NGOs, regional 
governments and private companies brings the model closer to the British proposal. On the other hand, the importance attributed to cultural diplomacy resembles the French model of public diplomacy. So, let's have a look at the Spanish model of public diplomacy. The institutional framework created by the Ministry of Foreign Affairs comprises the following agencies:

First, the 'Casas' Consortium is a project created in 1992, the aim of which is to strengthen ties with regions especially important for Spanish foreign policy. The Consortium comprises six 'Casas' located in different cities of Spain: Casa America (Madrid), Casa Africa (Canary Islands), Casa Arabe (Madrid), Casa Asia (Barcelona and Madrid), Casa Mediterraneo (Alicante) and Casa Sefarad (Madrid).

Second, the 'Fundacion Carolina' is a private-public foundation created in 2000. Its main purpose is to foster cultural and academic cooperation between Spain and Latin American countries.

Third, the Ministry of Foreign Affairs has created a network of Council Foundations ('Consejos'). Its aim is to promote and strengthen bilateral networks between Spain and important powers of international society. There are eight Council Foundations: Spain-United States, Spain-Japan, Spain-Russia, Spain-India, Spain-China, Spain-Mexico, and Spain-Australia.

Fourth, the 'Instituto Cervantes' was created in 1991 to promote the Spanish language and spread Spanish culture. Its headquarters is based in Madrid and Alcala de Henares, the city where Miguel de Cervantes was born. The 'Instituto Cervantes' is represented in 43 countries around the world and is inspired by its British and French counterparts. The 'Instituto Cervantes' has been one of the most successful tools of Spanish public diplomacy.

Finally, the AECID (The Spanish Agency for International Development Cooperation) was created in 1998. The AECID is a public agency that belongs to the Ministry of Foreign Affairs and its main aim is to fight global poverty and inequality. AECID's regional priorities are Latin America, the Maghreb, sub-Saharan Africa and South East Asia.

In the context of Spanish public diplomacy, I should highlight the efforts of the Ministry of Foreign Affairs to develop a policy of national (re)branding: 'Marca España'. This program is the most important project of Spanish public diplomacy. This project, which is based on consensus, is considered a long-term state policy with the purpose of transcending the political alternation. Marca España's main aim is to improve the image of Spain not only abroad but also in Spain itself. The improvement of the image of Spain should foster exports and attract foreign investment. In this same vein, thanks to Marca España Spanish companies carrying out investments abroad will find fewer obstacles to doing business.

In 2012 the government created the figure of the High Commissioner for Marca España who is directly appointed by the prime minister, although functionally dependent of the Ministry of Foreign Affairs. The current Commissioner is Carlos Espinosa de los Monteros, a prestigious professional with important experience in both the private and the public sectors. 


\section{Alberto Priego Moreno}

In the framework of Marca España, an initiative which has created a partnership with some of the most important Spanish companies, the Forum of the Leading Brands or 'Foro de Marcas Renombradas' (FMRE) has emerged. The FMRE, which was created in 1999, is an alliance between private and public institutions that try to promote the importance of the country's brands as a factor of competitiveness and internationalization of the Spanish economy. Fashion companies (Zara and Adolfo Dominguez), football teams (Real Madrid and Atletico de Madrid) and financial institutions (Banco Santander or BBVA) are active members of this ambitious program resulting from public-private cooperation.

Since 2005 the FMRE has been accrediting honorary ambassadors of Marca España. Prestigious sportsmen, businessmen and artists such as Amancio Ortega, Fernando Alonso and Placido Domingo, are some of the honorary ambassadors who work every day to improve the image of Spain. A similar program called Friends of Spain Brand (Amigos de la Marca España) aims to recognize outstanding foreign personalities with remarkable links with Spain. The former Russian Minister of Foreign Affairs, Igor Ivanov, and the founder of the brand that dresses the Spanish Olympic Committee, Li Ning, are two members of the program Friends of Spain Brand.

Needless to say, Marca España's main objective is only the promotion of Spain's image abroad. However, one may wonder what Marca España is made of, why Spain might be attractive for foreigners and how the Ministry of Foreign Affairs is using the concept. Marca España is a typical example of national branding and, in the case of Spain, should be named national rebranding. The main aim of this project is to overcome the image left by 40 years of isolationism under Franco's Regime. As Germany modified its own image after the Hitler period, Spain is trying to improve its international credibility with a very similar project. While Germany focused its rebranding efforts in the concept of 'effectiveness', essentially applied to the automotive industry (BMW, Porsche, Audi, etc.), Spain is seeking to combine its rich history with its modernity using sport, food and culture among other elements.

To conclude this section, I should point out that Marca España program responds to the need to improve and modernize the image of Spain abroad. Apart from that this state policy seeks to adapt the traditional Spanish Diplomacy to the paradigm, the Structural Diplomacy.

\section{Spanish commitment to international multilateralism: the role of Spanish diplomats}

Over the last 40 years, Spain has witnessed of a significant increase in the number of Spanish diplomats with international responsibilities. While during Franco's regime Spanish diplomats could not aim for international positions, today it is becoming more and more common to find Spanish diplomats working for NATO, UN or the European Union. The many diplomats and 
former politicians of international fame include the following: Javier Ruperez, Miguel Angel Moratinos, Javier Solana and Carlos Westendorf.

Javier Ruperez is a Spanish diplomat who served as President of the OSCE Parliamentary Assembly (1996-98). Ambassador Ruperez was appointed as Assistant Secretary General of the United Nations and executive director of the Counter Terrorism Committee of the Security Council (2004-7). He has been the Spanish diplomat who has achieved the widest range of experience at the international level. As a Spanish diplomat, he has been posted to Ethiopia, Poland and Finland, among other missions. In 1982 he became Spanish Ambassador to NATO (1982-87) and later to the United States (2000-2004).

Javier Solana is a politician who served as Minister of Foreign Affairs during the 1990s. In 1995 he became the first Spaniard to become NATO Secretary General. Four years later, he was appointed EU High Representative for the Common Foreign and Security Policy. In 2009 Catherine Ashton replaced Javier Solana as EU foreign policy chief.

Miguel Angel Moratinos is a Spanish diplomat who served as Minister of Foreign Affairs during Prime Minister Zapatero's government (2004-10). Previously, in 1996 Ambassador Moratinos was appointed EU Special Envoy for the Middle East Process where he enjoys great prestige as a diplomat. After his responsibility in the Ministry of Foreign Affairs Ambassador Moratinos was one of the candidates for the Presidency of the FAO.

Carlos Westendorf is a Spanish diplomat whose career has mostly been linked to international organizations. Ambassador Westendorf served as Secretary of State for the European Union (1991-95) and Minister of Foreign Affairs (1995-96) under the presidency of Felipe Gonzalez. In 1997 he was appointed United Nations High Representative for Bosnia and Herzegovina for a period of two years. In 2004 he was appointed Ambassador to the United States.

These four cases are just some examples of the new profile of the Spanish diplomat who has become a relevant actor involved in the configuration of the rules, costumes and institutions of international society.

\section{Spain's commitment to multilateralism}

Since its discovery, the Americas have been a geographic priority for Spanish foreign policy. Thus, during centuries of shared history Spain and Latin America have strengthened their social, political and cultural links. For this reason and, in spite of a period in which the two regions maintained significant differences, we can, in general, state that Spain and Latin America have constituted a community of values. One of the causes of this excellent relationship has been the Ibero-American Summit. These summits bring together the Heads of State and Government of Latin America plus Spain and Portugal. In 1991, Mexico organized the first summit in Guadalajara (Mexico), and the Head of States and Governments of Latin America, 
Portugal and Spain attend annual meetings to discuss relevant issues for the Ibero-American Community of Nations.

The Ibero-American Summits are a useful and interesting instrument for Spanish foreign policy. On the one hand, Spain and Portugal have improved their images among their former colonies, eliminating neo-colonialist mistrust. Today Latin America is gaining in importance for both Spain and Portugal. The reason is that Latin America includes some of the most promising economies in the world, such as Brazil, Mexico and Chile. Therefore Lisbon and Madrid needed to improve relations with their former colonies and the Ibero-American Summits are an excellent option. On the other hand, Portugal and Spain have developed a new model of relations with Latin America that strengthens their position vis-á-vis their European partners. It can be said that Spain is the gateway to Europe for Latin American countries and, at the same time, the spokesman of these emerging powers in the European Union.

In connection with this process, in 2004 the Spanish Ministry of Foreign Affairs created the position of Ambassador on Special Mission for the Ibero-American Summit and Multilateral Affairs. From that date, different diplomats have been accredited to assume this task: Diego Bermejo Romero (2011-13), Juan Maria Alzina de Aguilar (2010-11), Ricardo Peidro Conde (2009-10), Anunciada Fernandez de Cordova (2006-9), Maria Jesus Figo (2005-6) and Yago Pico de Coaña y Valicourt (2004-5).

Although the figure of the special mission has been described as a 'Third World' instrument, Spain is an enthusiastic defender of this practice. Regarding Spanish diplomacy towards Latin America, I cannot share this premise because Spain has a long tradition of resident ambassadors accredited to all the states of Latin America including English-(Belize) and Portuguese-speaking states (Brazil). However, the Ministry of Foreign Affairs employs the Ambassador on Special Mission as an ad hoc instrument of foreign policy. The Ambassador on Special Mission for the Ibero-American Summits should be understood as an indicator of Spanish willingness to institutionalize an international regime that is not yet mature.

Finally, the Ibero-American Summits are an enlightening example of structural diplomacy. On the one side, through these summits Spain is trying to exert influence on the structure of the international system, or at least to be the leader in the bilateral relationship between Latin America and Europe. On the other side, Spain is committed to a model of sustainable diplomacy that promotes stability and mutual understanding (Aldecoa and Sotillo 2006: 328).

The Mediterranean Sea has been another priority for Spain, especially since Franco's death. Spain has created, contributed and supported many initiatives to promote stability, peace and prosperity in the Mediterranean region. So, I can stress among other initiatives the NATO Mediterranean Dialogue, the OSCE Mediterranean Partnership and the Dialogue 5+5. Needless to say, the most important and successful Spanish initiative has been the Euro-Mediterranean Conference held in Barcelona in 1995. During the 
Spanish EU Presidency (Barbe 2008: 3), Javier Solana - Minister of Foreign Affairs in 1995 - described the initiative as "a process to foster cultural and economic unity in the Mediterranean region" (Soto 2009).

The Euro-Mediterranean Partnership is a good example of this new way of doing diplomacy adopted by Spain after 1975. On the one hand, the process has helped to enhance the Spanish image abroad, not only on the Southern Mediterranean shore but also among the European partners. On the other hand, the Barcelona Process can be considered a proper example of structural diplomacy. The Euro-Mediterranean Partnership helped to create new rules or customs such as the participation of non-state actors in the Mediterranean Dialogue. Thank to this Spanish initiative the Arab League, the Palestine Authority and the European Parliament are more involved in the dynamics of the Mediterranean region.

In other words, Spain showed that it is capable of improving its troubled and messy relations with North African partners using the Barcelona Process. This initiative is an example of structural diplomacy because it modifies the rules of the games promoting cooperation in the dynamic between the two regions and creating a handier environment in the whole Mediterranean Sea. Apart from the Ambassador-at-large established in the Mediterranean capitals, the Spanish Ministry of Foreign Affairs created the position of the Ambassador on Special Mission for Mediterranean Affairs. Since 2000, Madrid has accredited different diplomats as Ambassadors on Special Mission for Mediterranean Affairs: Juan Jose Escobar (2011-13), Jose Riera (2008-11), Fidel Sendagorta (2007-8), Joan Prat i Coll (2004-7), Eudaldo Mirapeix y Martinez (2000-2004) and Pedro Lopez Aguirrebengoa (2000-2001).

The United Nations Alliance of Civilizations (UNAOC) is an initiative proposed by Prime Minister Zapatero and supported by Turkish Prime Minister Tayip Erdogan. The UNAOC was announced in New York at the 59th Assembly of the United Nations in 2005. Its main purpose is to promote tolerance and respect among peoples from different cultures and religions (Soler i Lecha 2011: 431).

From the very beginning, Prime Minister Zapatero expressed his commitment to the project. In 2005, he appointed a prestigious Spanish diplomat, Ambassador Maximo Cajal, as Special Representative of the Spanish Prime Minister to the Alliance of Civilizations project. As well as his personal representative, the prime minister also created a diplomat position to represent the Spanish side in the UNAOC (Cajal 2011: 47). In 2008 another diplomat, Belen Alfaro, was nominated as Ambassador on Special Mission to the Alliance of Civilizations. Three years later, another diplomat, Victoria Gonzalez, assumed the challenge and the responsibility of representing Spain in this innovative forum.

The UNAOC is an excellent example of structural diplomacy because it reflects the two aspects of the concept: on the one hand the UNAOC has a structural component because it tries to exert influence over the relations among the civilization; on the other hand, the UNAOC should be considered 
a sustainable initiative taking into account that it seeks the promotion of a more tolerant and peaceful international society.

Moreover, the UNAOC is a fantastic tool for Spanish diplomacy because Spain has adopted a tolerant and cooperative position to face the challenge in an increasingly conflicting world. This initiative is helping to ensure that the image of Spain appears - especially among the non-Christian partners - as an attractive partner for trade and cooperation.

\section{The reform of the Spanish Diplomatic Service}

The Spanish Diplomatic Service was established in 1844 by the Minister of State, Bravo Gonzalez. During the nineteenth and twentieth centuries the Spanish aristocracy occupied some of the most important positions in the Spanish Diplomatic Service. Spain opted for the French model of diplomacy and therefore, for a long time, the prevailing language was French (Nicholson: 1954); English was not introduced as working language until 1932. In 1942 the Minister of Foreign Affairs created 'La Escuela Diplomatica', a diplomatic school that followed the philosophy of other centers such as the Foreign Service Institute in the United States or The Ecole Diplomatique et Consulaire in France.

During Franco's regime, the Spanish Diplomatic Service remained practically unchanged. For this reason, it was necessary to wait until the democratic period to appreciate the first substantial effort to reform the Spanish Diplomatic Service. I can stress two major attempts: the first came with the integration of Spain into the European Union, in 1986, and the second one was promoted by Prime Minister Zapatero 20 years later. However, none of these two reforms implied the adoption of a new law for the Diplomatic Service. This legal reform began to be processed in 2013 and was due to enter into force in 2014.

The first attempt to reform, which was promoted by the Minister of Foreign Affairs Fernando Moran, was intended to adapt the Spanish Diplomatic Service to EU standards. The Ministry of Foreign Affairs made an assessment of the situation of Spanish diplomacy and published the report Libro Blanco sobre la Administracion Exterior del Estado, the conclusions of which were devastating - namely that there was an imbalance between the goals and the means. To solve this imbalance, prime ministers Gonzalez and then Aznar adopted two legislative acts on the Spanish Diplomatic Service. The first one, the 'Royal Decree on the Organization of the State abroad', adopted by Gonzalez's government, was approved in 1987. The second one, the 'Organic law on the functioning of the General Administration of State Abroad', was adopted during Aznar's first presidential term in 1997.

Both the Decree and the Law did not account for a comprehensive reform of the Spanish Foreign Service. Therefore, the Minister of Foreign Affairs Miguel A. Moratinos undertook the second reform of the Spanish Diplomatic Service that was due to culminate in 2014. The first phase of the reform 
was the elaboration of a report to identify the main problems of the Spanish Foreign Service. The report is divided into three different parts: the first part is devoted to the analysis of the changes in international society and how these changes are affecting Spanish diplomacy; the second is an assessment of the current situation of the Spanish Diplomatic Service (a worrying lack of participation of the civil society in the making of Spanish foreign policy was stressed in the report); and the third is focused on measures that must be implemented to solve the problems of the Spanish Foreign Service. Among the proposals we could mention an increase in resources; the elimination of political ambassadors; and a better coordination through the Council of Foreign Policy (Consejo de Politica Exterior).

It can be said that this reform, which began in 2005, is the attempt to adapt the Spanish Foreign Service to the changes and challenges of international society. Thus, these facts prove one of the elements suggested at the beginning of this chapter: the need to adapt Spanish diplomacy to an evolving international society. Again, the different attempts to reform are examples of the willingness of governments to adapt Spanish diplomacy to the new international environment.

Moreover, a modern diplomatic corps, adapted to the needs of a middle power (what Spain wants to be), will be the best public diplomacy for a state with international aspirations. The first public image of a state is its embassies and diplomats. For this reason, it is necessary to accomplish a real reform of the Spanish Diplomatic Service to promote the image of Spain as a democratic and modern state. If the Government culminated this task that began in 1986, Spain would not only improve its image, but also it could achieve a better position within international society. All these reformist efforts were due to culminate in 2014 with approval of the External Action Act, which should be understood within the theoretical framework of structural diplomacy.

\section{Conclusions}

From the previous pages, I can conclude that from 1975 until 2011 Spanish diplomacy has experienced a substantive change. In 1975, after Franco's death, Spain came out of a non-democratic period and undertook a new venture. However, despite the changes carried out by the different governments and civil society, there is still room to improve the image of Spain at international level.

Moreover, international society began to change in a vertiginous way; important events such as the fall of the Berlin wall, the integration of Spain into the EU and the internationalization of Spanish companies such as Zara, Repsol and Santander made explicit the need to transform the traditional Spanish model of diplomacy into a non-traditional one. For instance, a nontraditional model of diplomacy would give greater importance to economic and business aspects. Thus, the leading companies would find it easier to internationalize. 
For these reasons, Gonzalez's government began a comprehensive transformation process of Spanish diplomacy that was due to culminate in 2014 with the External Action Act. This transformation, whose objectives were to improve the image of Spain and to adapt Spanish diplomacy to the new world order, should be understood in the theoretical framework of structural diplomacy. The author of the term, Keukeleire, attributes two characteristics to the term 'structural': the first meaning refers to organizing principles, rules of the game and institutions; the second meaning should be understood as a long-term approach of this diplomatic influence.

All the changes in Spanish diplomacy are inspired by structural diplomacy. Some initiatives, such as the Ibero-American Summits or the Marca España program, are aimed at improving the image of Spain at international level. Others, however, such as the reforms of the Spanish Diplomatic Service, seek to adapt Spanish diplomacy to a new international reality.

\section{Bibliography}

Aldecoa, F. and J.A. Sotillo. (2007). 'Claves para interpretar la Politica Exterior Española y las Relaciones Internacionales en 2006.' Anuario Internacional CIDOB 1: $325-7$.

Alonso, G., J.L. Manfredi, and R. Rubio. (2012). Retos de nuestra accion exterior: Diplomacia Publica y Marca España. Madrid: Cuadernos de la Escuela Diplomatica. Berridge, G.R. (2012). Embassies in armed conflict. New York: Continuum.

(2010) Diplomacy: Theory and Practice, 4th edn. Basingstoke, UK: Palgrave Macmillan.

(2004) Diplomatic classics: selected texts from Commynes to Vattel. Basingstoke, UK: Palgrave Macmillan.

Berridge, G.R., M. Keens-Soper and T.G. Otte. (2001). Diplomatic Theory from Machiavelli to Kissinger. Basingstoke: Palgrave MacMillan.

Barbe, E. (2008). Spain in Europe 2004-2008 Bellaterra: Institut Universitari d'Estudis Europeus.

Barston, R.P. (2006). Modern Diplomacy. Harlow: Pearson.

Cajal, M. (2006). 'The Alliance of Civilizations: A Spanish View', Insight Turkey 3: $45-55$.

Constantinou, C.M. and J. Der Derian. (2010). Sustainable diplomacies. New York: Palgrave Macmillan.

Cross, M.K.D. (2007). The European Diplomatic Corps: Diplomats and international cooperation from Westphalia to Maastricht. Basingstoke, UK: Palgrave Macmillan.

Cummings, M. (2003). 'Cultural Diplomacy and the United States Government: a Survey.' Washington DC: Center for Art and Culture.

Eban, A.S. (1983). The New Diplomacy: International Affairs in the modern age. New York: Random House.

Elman, C. and M.F. Elman (1997) 'Diplomatic History and International Relations Theory.' International Security 1: 5-21.

Hayden, C. (2012). The rhetoric of soft power: public diplomacy in global contexts. Lanham: Lexington Books.

Jönsson, C. and M. Hall. (2005). Essence of diplomacy. New York: Palgrave Macmillan. 
Kelley, J.R. (2010). 'The New Diplomacy: Evolution of a Revolution.' Diplomacy \& Statecraft 2: 286-305.

Kelman, I. (2012). Disaster diplomacy: how disasters affect peace and conflict. Abingdon, UK: Routledge.

Kennan, G.F. (1997). 'Diplomacy without Diplomats?' Foreign Affairs 5: 198-212.

Keukeleire, S., R. Thiers, and A. Justaert. (2009). 'Reappraising Diplomacy: Structuctural Diplomacy and the Case of the European Union.' The Hague Journal of Diplomacy 4: 143-65.

Keukeleire, S. (2003). 'The European Union as a Diplomatic Actor: Internal, Traditional, and Structural Diplomacy.' Diplomacy \& Statecraft 3: 31-56.

Leguey-Feilleux, J. (2009). The dynamics of diplomacy. Boulder, COL: Lynne Rienner.

Mead, W.R. (2004). 'America's Sticky Power.' Foreign Policy, March/April 2004, 46-53.

Manfredi, J.L. (2011). 'Hacia una teoria de la comunicacion de la diplomacia publica.' Comunicacion y Sociedad 2: 199-225.

McKercher, B.J.C. (2012). Routledge handbook of diplomacy and statecraft. Abingdon: Routledge.

Melissen, J. (2007). The New public diplomacy: soft power in International Relations. Basingstoke, UK: Palgrave Macmillan.

Nicholson, H. (1954). The Evolution of the Diplomatic Method. London: Constable.

Nye, J.S. (2004). Soft Power: the means to success in world politics. New York: Public Affairs.

Pinfari, M. (2013). Peace negotiations and time deadline diplomacy in territorial disputes. London: Routledge.

Priego, A. (2011). 'El Servicio Exterior Español: Una vision critica desde su Creacion hasta la Reforma de 2006.' UNISCI Discussion Papers 27: 9-24.

Sarvary, K. (2001). 'Devaluing Diplomacy? A Critique of Alexander Wendt's Conception of Progress and Politics.' Journal of International Relations \& Development 4: 380-402.

Seib, P.M. (2012). Real-time diplomacy: politics and power in the social media era, 1st edn. New York: Palgrave Macmillan.

Senn, A.E. (1974). Diplomacy and revolution: the Soviet mission to Switzerland. Notre Dame: University of Notre Dame Press.

Sharp, P. (2009). Diplomatic theory of international relations. Cambridge: Cambridge University Press.

(1999). 'For Diplomacy: Representation and the Study of International Relations.' International Studies Review 1: 33-57.

Sigsgaard, J.N. (2011). The New era of Diplomacy: the effects of public diplomacy, nation branding and cultural diplomacy. Saarbrücken: Lap Lambert.

Simpson, S. (1972). Instruction in diplomacy: The liberal arts approach. Philadelphia: American Academy of Political and Social Science.

Soler i Lecha, Eduard. (2011). 'Las relaciones hispano-turcas: buena sintonia pese al estancamiento europeo.' Anuario Internacional CIDOB 5: 427-33.

Soto, A. (2009). 'Javier Solana: Ten years as Mr. Europe.' Private in Flight Magazine 3.

Van Ham, P. (2001). 'The Rise of Brand State: Postmodern Politics of Image and Reputation.' Foreign Affairs 5: 2-6.

Windhal, U. and B.H. Signitzer (2009). Communication Theory: An Introduction to Planned Communication. London: Routledge. 